\title{
THE IMPACT OF VISIONARY LEADERSHIP, LEARNING ORGANIZATION AND INNOVATIVE BEHAVIOR TO PERFORMANCE OF CUSTOMS AND EXCISE FUNCTIONAL
}

\author{
Muhammad Anshar \\ Tanjung Priok Customs and Excise Service Office \\ muh_anshor@yahoo.co.id
}

\begin{abstract}
This research aims to determine the impact of visionary leadership, learning organization, and innovative behavior on the performance of Functional Officers of Customs and Excise Inspectors at Tanjung Priok Customs and Excise Main Service Office. The research was conducted at Tanjung Priok Customs and Excise Service Office using the number of samples of 78 Functional Officers of Customs and Excise Inspectors. The sample was selected using simple random sampling technique. Data collection was done by using questionnaire and data analysis using path analysis. The results showed that 1) visionary leadership, learning organization and innovative behavior have a direct and positive impact on performance, 2) visionary leadership, and learning organization have a direct and positive impact on innovative behavior and 3) visionary leadership have a direct and positive impact on learning organization. The conclusion of this research is to improve the performance of Functional Officer of Customs and Excise Inspectors at TanjungPriok Customs and Excise Main Service Office, it is necessary to increase the aspect of visionary leadership from Head of Main Service Office, learning organization at Main Service Office and innovative behavior at Functional Officers of Customs and Excise Inspectors.
\end{abstract}

Keywords : visionary leadership, learning organization, innovative behavior, and Performance.

One of the vertical offices of the Directorate General of Customs and Excise which has considerable activity in import and export activities is the Tanjung Priok Customs and Excise Main Service Office. Tanjung Priok Main Customs Service Office becomes a barometer in performance appraisal of the Directorate General of Customs and Excise because this office has activities both in terms of volume and the largest number in Indonesia. From the state revenue side can be seen on the table 1.2 below:

Table 1.2Target dan Realization of Import Duty, Export Duty and Excise Tanjung Priok Customs and Excise Main Service Office

\begin{tabular}{|c|c|r|r|r|r|r|r|r|c|}
\hline \multirow{2}{*}{ Tahun } & \multicolumn{4}{|c|}{ Target } & \multicolumn{4}{c|}{ Realisasi } & Capaian \\
\cline { 2 - 10 } & $\begin{array}{c}\text { Bea } \\
\text { Masuk }\end{array}$ & Cukai & $\begin{array}{c}\text { Bea } \\
\text { Keluar }\end{array}$ & Total & $\begin{array}{c}\text { Bea } \\
\text { Masuk }\end{array}$ & Cukai & $\begin{array}{c}\text { Bea } \\
\text { Keluar }\end{array}$ & \multicolumn{1}{c|}{ Total } & Total \\
\hline 2014 & $18.001,53$ & 0,65 & 106,30 & $18.108,48$ & $15.885,88$ & 0,67 & 69,27 & $15.955,82$ & $\mathbf{8 8 , 1 1 \%}$ \\
\hline 2015 & $18.194,39$ & 0,80 & 52,48 & $18.247,67$ & $14.909,92$ & 0,93 & 4,88 & $14.915,73$ & $\mathbf{8 1 , 7 4 \%}$ \\
\hline $2016^{\star}$ ) & $17.894,26$ & 0,35 & 2,88 & $17.897,49$ & $6.108,47$ & 0,00 & 0,93 & $6.109,4$ & $\mathbf{3 4 , 0 9 \%}$ \\
\hline
\end{tabular}

From the above table it is known that in 2014, Tanjung Priok Customs and Excise Main Service Office can realize its target of only $88.11 \%$ of total Revenue(import duty, export duty and excise) of Rp18,108.48 Billion. While in 2015, the realization of nominal revenue is smaller than in 2014 and the realization is only reached $81.74 \%$ of the target revenue 2015.The low realization of the target in 2014 and 2015 may be affected by the performance of Functional Officers of Customs and Excise Inspectors tasked with conducting research of import documents at Tanjung Priok Customs and Excise Service Office. According to the Regulation of the Minister of Finance No. 184 / 
PMK.04/ 2014 on Technical Guidelines for the Functional Officials of Customs and Excise Inspector and Credit Score, the Customs and Excise Inspector is a Civil Servant who is fully functionally assigned, duties, powers and entitlements Authorized officials to carry out customs and excise inspections, prevention of violations of laws and criminal investigations in the field of customs and excise. The elements of customs and excise inspection activities consist of: receipt of documents, document examination, Inspection of goods, Body check, Inspection of carrier means, Inspection of buildings and installations,verification of documents, and customs and excise audits. Thus the role of functional officials is vital, so the performance of functional officers of the Customs and Excise Inspector greatly determines the performance of DGCE as a whole.

However, the pre-research orientation at the Tanjung Priok Main Service Office of Customs and Excise shows that there are still Functional Officers of Customs and Excise Inspectors who are less able to demonstrate their best working behavior, such as lack of enthusiasm in work, unable to empower the potential possessed by the examiner optimally, Lack of dedication in striving for DGCE goals. In addition, the performance of Functional Officials of Customs and Excise Inspectors also indicates less than the maximum. This can be seen from:

1. The value of findings for examination documents imports are declining. In 2013, the findings of import document examination reached Rp 1.09 trillion, while in 2014 it only reached Rp 1.03 trillion and in 2015 only reached Rp 0.76 trillion or the value of findings decreased by $5.5 \%$ and $26.2 \%$ respectively in 2014 and 2015 . The decline in these findings contributes to the nonachievement of the target of receiving the Main Service Office of Customs and Excise Tanjung Priok in 2014 and 2015.

2. Increasing of Audit finding in 2014 and 2015 in the post clearance audit indicated that Customs and Excise Functional Official less careful in conducting examination of import document.

Based on the above explanation, it is need to improve comprehensive in order to increase Functional Officials performance. Increasing on Functional Officials performance will be effected to state revenue increasing. The improvement are needed on leader side such as visionary leadership on head of customs and excise main service office, on the office side such as learning organization on Tanjung Priok customs and excise main service office and on functional officials side such as innovative behavior. So that, this research focused to visionary leadership, learning organization and innovative behavior relating the performance of functional officials

Many definitions are advanced by experts relating performance. According to Ivancevich, Konopaske, and Matteson ${ }^{[1]}$ said that Performance is a unity of work associated with employee behavior designed to achieve organizational goals. Whereas, Aguinis ${ }^{[2]}$ states that Performance is about behavior or what employees do, not about what employees produce or the results of their work. Brumbrach as quoted by Armstrong ${ }^{[3]}$ stated that performance has a meaning of behavior and results. Behavior comes from executors and transfers performance from abstract to action. Not only instruments for results, behavior is also the result of itself a mental product and the application of physical effort to the task and can also be judged part of the result. Colquiet, Lepine, and Wesson ${ }^{[4]}$ affirm that performance is a series of employee performance that contribute both positively and negatively to the achievement of organizational goals. This definition of performance includes behaviors that control employees, but the behavior has restrictions on the behavior both relevant (and irrelevant) to job performance.

Based on the above description, it can be synthesized that performance is the behavior of a person displayed in completing the task as the organization rule, with an indicator: persisting with enthusiasm and expending more effort, doing activities that formally become his duty, assisting and cooperating with other employees, To follow organizational rules and procedures, and to cultivate, support and defend the goals of the organization.

Komariah and Triatna ${ }^{[5]}$ argue that visionary leadership is the ability of leaders to create, formulate, communicate and implement ideal thoughts derived from him or as a result of social 
interaction among members of the organization and stakeholders who are believed to be the ideals of the organization in the future that must Achieved and realized through the commitment of all personnel. According to Marno ${ }^{[6]}$ Visionary leaders are leaders who have and always oriented to the future, what would want to be realized in the future of the reality being faced. For the visionary leader, when he saw the stone for example. In his mind was the desire to make a big house and magnificent. The visionary leader is important and determines the life of the organization. Furthermore Marno, the ability of leaders to create a vision and translate it into reality is called visionary leadership. Visionary leadership is an attractive target so that commitment and all personnel to achieve it. Leaders must formulate their own vision by involving people or teams to help formulate them. Vision can include quantitative goals such as targets expressed as percentages, or can state years of achievement, and may also only describe future conditions to be achieved.

On the other hand, Goleman ${ }^{[7]}$ argues that visionary leadership is a leadership pattern that seeks to encourage people toward dreams along with the most positive and most appropriate emotional climate impacts used when change requires a new vision or when a clear direction is needed. This means that visionary leadership is needed in changing organizational conditions and requires a new vision or vision change.

Thus visionary leadership can be synthesized that visionary leadership is a leader action that can influence or encourage others to create and articulate realistically, credibly and attractively about future visions that can improve the current state, with indicators: setting superior standards and reflecting High ideas, clarify goals and direction, inspire spirit and keep commitment, have good pronunciation and easy to understand (effective communication), reflect the uniqueness of different organizations and competencies, and have a strong determination to realize the ideals.

According to Tjakraatmadja, Hidayat and Lantu ${ }^{[8]}$, learning organization can be defined as an organization that has the ability to always improve performance in a sustainable and cyclical manner, because its members have individual commitment and competence that is able to learn and share knowledge at superficial and substantial level.whereas according to Robbins and Coutler ${ }^{[9]}$, learning organization is an organization that has evolved its capacity to constantly learn, adapt and change. Senge as quoted by Armstrong ${ }^{[10]}$ argues that "learning organization as a whole where people continue to develop the capacity to make a result they really want, where a new, elastic mindset can be maintained, where free responses are collected, and where people People learn how to learn together continuously. Understanding the learning organization also proposed by Jones ${ }^{[11]}$ which says Learning organization is an organization that deliberately design and build structures, cultures, and strategies so as to enhance and maximize the potential learning organization that is underway. While Drafke ${ }^{[12]}$ sees Learning organization as an organization focused on improving learning and knowledge disseminated throughout the company. Greenberg and Baron ${ }^{[13]}$ explain that the Learning organization is an organization that successfully obtain, process, and apply knowledge that can be used to assist in adapting to a change. In line with the views of Greenberg and Baron above, Certo and Certo ${ }^{[14]}$ argue, Learning organization is a good organization in creating, acquiring, and transferring knowledge, and modifying behavior to reflect new knowledge.

Learning organization is also defined by Garvin as quoted Tjakraatmadja and Lantu ${ }^{[15]}$, essentially explaining that learning organization is an organization that has the ability to create and build knowledge / information organization through the process of knowledge transformation from individual competence to knowledge organization (human capital). Learning organizations are able to motivate all employees to be willing and able to improve their daily behaviors, reflected in paradigm improvements (views and ways of thinking), as well as increased intelligence (balance between intellectual, emotional and spiritual intelligence) and the expansion of employee insight.

Based on the above description it can be synthesized that the Learning Organization is an organizational capability that continuously extends its capacity to create a truly desired outcome by nurturing new thinking and expansion patterns, collective free regime aspirations, and how to learn 
together, with indicators: managerial commitment, System perspectives, openness and experimentation, as well as transfer and integration of knowledge.

The concept of innovative behavior, according to Carmeli, Meitar and Weisberg ${ }^{[16]}$ is a gradual process in which individuals recognize a problem to derive new ideas and solutions, work to advance and build support for it, and produce a prototype that is applied or a model to use and benefit Organization or part thereof.

Innovative behavior is an innovation that is done individually. Scott and Bruce as quoted by Cingöz and Akdo ${ }^{[17]}$ explain that individual innovation begins with the decline of ideas, namely the production and use of new ideas in several domains. The next stage of the innovation process is the promotion of ideas for potential merger. Once an individual generates an idea, then the individual gets into a social activity finding friends, supporters, and sponsors or building a coalition of supporters who give important powers to the realization of ideas. The final task of the innovation process relates to the realization of an idea by producing a prototype or a perceived innovation model and apex is applied in an overall work, group, or organization role.

West and Farr as quoted by Kleysen and Street ${ }^{[18]}$ explain that innovative behavior is an individual action directed toward generating, introducing or applying new findings that are profitable at every level of the organization. New findings such as the development of new product ideas or technologies, change administrative procedures aimed at improving working relationships or applying new ideas or technologies to work processes aimed at significantly improving efficiency and effectiveness.

Based on the above explanation, it can be synthesized that innovative behavior is an individual action directed to produce, introduce or apply new findings in the form of ideas and solutions that benefit the organization, with indicators: exploring opportunities, generativity, conducting informative investigations, championing and applying of new idea.

Based on the above matters, in general the purpose of this study is to reveal whether or not the influence between variable variables studied, either direct or indirect influence with the description as follows:

First, to determine whether there is a direct influence of visionary leadership on performance, second To determine whether there is a direct influence of learning organization on performance, Third, to determine whether there is direct influence of innovative behavior toward performance, fourth, to determine whether there whether there is direct influence of visionary leadership toward innovative behavior, Fifth to determine whether there is direct influence of learning organization to behavior Innovative, and the last to determine whether there is a direct influence of visionary leadership on learning organization.

\section{METHOD}

This research was conducted at Tanjung Priok Customs and Excise Service Office in January until November 2016. This research used quantitative approach with survey technique. The population of this research is 98 Functional Official of Customs and Excise Inspector. Sampling was done by using simplerandom sampling technique. The research data collected through questionnaires, including performance data, visionary leadership, learning organization, and innovative behavior.

\section{RESULT}

Based on the results of data processing research using SPSS Version 21.0 can be categorized in three condition as follow:

1. The Impact of Visionary Leadership (X1), Learning Organization (X2) and Innovative Behavior (X3) on Performance (Y) of Customs and Excise Functional Official. 
Table 1: The result of regression of Variabel X1, X2, X3 and Y

Coefficients $^{\mathrm{a}}$

\begin{tabular}{|ll|c|c|c|c|c|}
\hline \multirow{2}{*}{ Model } & \multicolumn{2}{|c|}{$\begin{array}{c}\text { Unstandardized } \\
\text { Coefficients }\end{array}$} & $\begin{array}{c}\text { Standardized } \\
\text { Coefficients }\end{array}$ & & \\
\cline { 2 - 5 } & B & Std. Error & Beta & t & Sig. \\
\hline 1 (Constant) & 46.133 & 7.760 & & 5.945 & .000 \\
& KEP_VISIONER & .281 & .066 & .333 & 4.278 & .000 \\
\cline { 2 - 5 } & LEARNING_ORG & .244 & .049 & .395 & 5.015 & .000 \\
\multicolumn{2}{|c|}{ INNOVATIVE BEHAVIOR } & .121 & .033 & .299 & 3.661 & .000 \\
\hline
\end{tabular}

Dependent Variable: KINERJA

Based on above Table, it as acquired that path coeffisient of visionary leadership (X1) on performance $(\mathrm{Y})$ is 0.333 with thitung value is 4.278 , while ttablevalue is 1.993 . as thitung value is greater than ttablevalue, Ho is rejected and $\mathrm{H} 1$ is accepted. So that, it can be concluded that visionary leadership (X1) has direct and positive impact to performance (Y).Whereas, path coeffisient calculation of learning organization (X2) on performance $(\mathrm{Y})$ is 0.395 with thitung value is 5.015 , while ttable valueis 1.993. as thitung value is greater than ttable value, Ho is rejected and $\mathrm{H} 1$ is accepted. So that, it can concluded that learning organization (X2) has direct and positive impact to performance $(\mathrm{Y})$. While, path coeffisient calculation of innovative behavior (X3) on performance $(\mathrm{Y})$ is 0.299 with thitung value is 3.661 , while ttable valueis 1.993 . as thitung value is greater than ttable value, Ho is rejected and $\mathrm{H} 1$ is accepted.So that, it can concluded that innovative behavior (X3) has direct and positive impact to performance (Y).

2. The Impact of Visionary Leadership (X1), and Learning Organization (X2) on Innovative Behavior (X3) of Customs and Excise Functional Official.

Table 2: The result of regression of Variabel X1, X2, X3 and Y

Coefficients $^{\mathrm{a}}$

\begin{tabular}{|c|c|c|c|c|c|}
\hline \multirow[b]{2}{*}{ Model } & \multicolumn{2}{|c|}{$\begin{array}{l}\text { Unstandardized } \\
\text { Coefficients }\end{array}$} & \multirow{2}{*}{\begin{tabular}{|l|}
$\begin{array}{l}\text { Standardized } \\
\text { Coefficients }\end{array}$ \\
Beta \\
\end{tabular}} & \multirow[b]{2}{*}{$\mathbf{t}$} & \multirow[b]{2}{*}{ Sig. } \\
\hline & B & Std. Error & & & \\
\hline \begin{tabular}{|ll}
1 & (Constant)
\end{tabular} & -38.970 & 26.786 & & -1.455 & .150 \\
\hline KEP_VISIONER & .675 & .216 & .323 & 3.121 & .003 \\
\hline LEARNING_ORG & .543 & .158 & .356 & 3.437 & .001 \\
\hline
\end{tabular}

Dependent Variable: PERILAKU_INOVATIF

Based on above Table, it as acquired that path coeffisient of visionary leadership (X1) on innovative behavior (X3) is 0.323 with thitung value is 3.121 , while ttable valueis 1.993 . as thitung value is greater than ttable value, Ho is rejected and $\mathrm{H} 1$ is accepted.So that, it can concluded that visionary leadership (X1) has direct and positive impact to innovative behavior (X3) . Whereas, path coeffisient of learning organization (X2) on innovative behavior (X3) is 0.356 with thitung value is 3.437, while ttable valueis 1.993. as thitung value is greater than ttable value, Ho is rejected and $\mathrm{H} 1$ is accepted. So that, it can concluded that learning organization (X2) has direct and positive impact to innovative behavior (X3).

3. The Impact of Visionary Leadership(X1 on Learning Organization(X2) of Tanjung Priok Customs and Excise Main Service Office.

Table 3: The result of regression of Variabel $\mathrm{X} 1, \mathrm{X} 2, \mathrm{X} 3$ and $\mathrm{Y}$

\section{Coefficients $^{\mathrm{a}}$}




\begin{tabular}{|ll|l|l|l|l|l|}
\hline \multirow{2}{*}{ Model } & \multicolumn{2}{|l|}{$\begin{array}{l}\text { Unstandardized } \\
\text { Coefficients }\end{array}$} & \multicolumn{2}{|l|}{$\begin{array}{l}\text { Standardized } \\
\text { Coefficients }\end{array}$} & & \multirow{2}{*}{ Sig. } \\
\cline { 2 - 6 } & B & Std. Error & Beta & .003 \\
\hline 1 & (Constant) & 56.728 & 18.318 & & 3.097 & .000 \\
\hline
\end{tabular}

Dependent Variable: LEARNING_ORG

Based on above Table, it as acquired that path coeffisientof visionary leadership (X1) on learning organization (X2) is 0.393 with thitung value is 3.731 , while ttable valueis 1.993 . as thitung value is greater than ttable value, Ho is rejected and $\mathrm{H} 1$ is accepted. So that, it can concluded that visionary leadership (x1) has direct and positive impact to learning organization (X2).

\section{DISCUSSION}

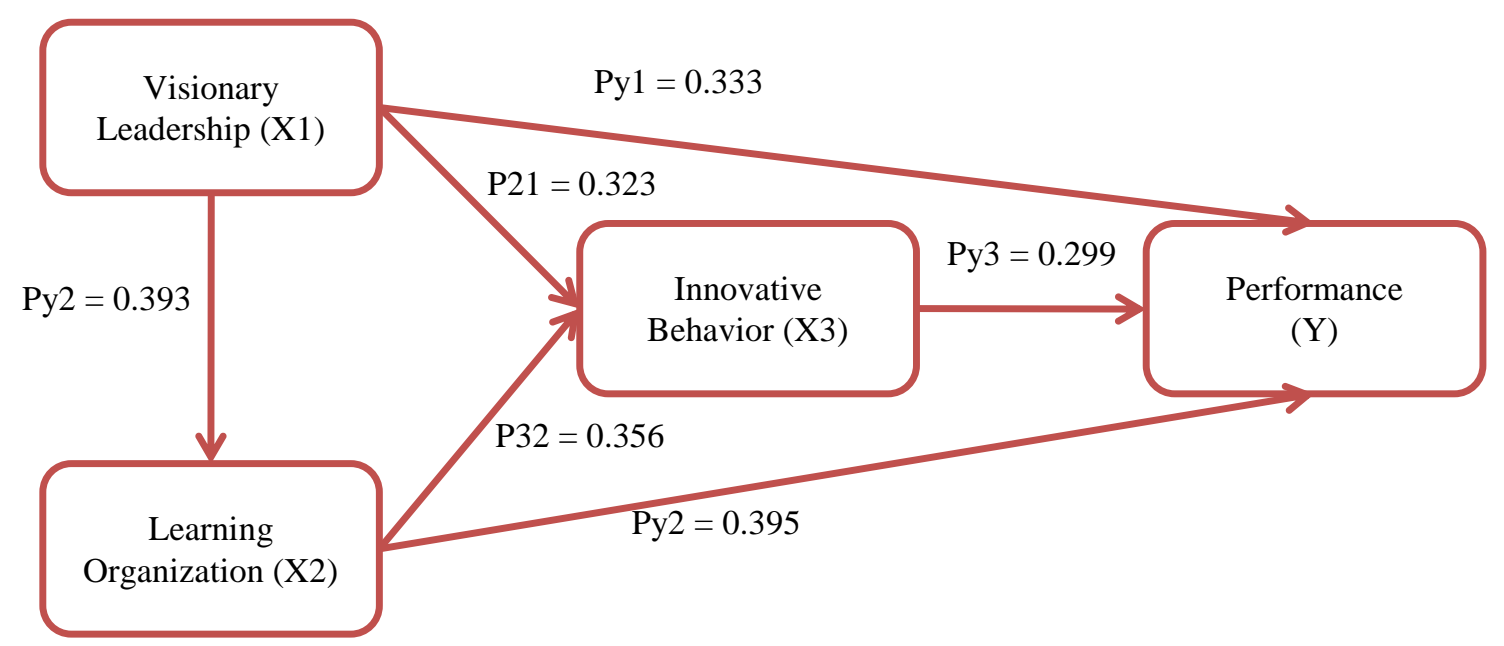

Figure 1. Scheme of Research

The result of statistical examination shows that visionary leadership has a direct and positive influence on performance. It is understandable that employee performance will be greatly influenced by the leadership of a leader. The visionary leader can encourage his employee to improve their performance in order to achieve the vision and mission desired by the leader. The results of this study reinforce previous research conducted by Juhana and Ambarsari ${ }^{[19]}$ who examined the Department of Mining and Energy of West Java Province involving 107 samples. The results showed that visionary leadership affect performance through job satisfaction variable of 0.746 . Thus visionary leadership greatly affects the performance of employees of the Department of Mining and Energy of West Java Province. Other Research conducted by Cheema, Akram and Javed who examines the effect of employee engagement and visionary leadership on job satisfaction and employee performance at 22 restaurants in Pakistan. The results show that visionary leadership has a direct and positive influence on job satisfaction and employee performance. The results of this research and some previous research also reinforce the opinions of experts on the importance of visionary leadership on performance. The opinions expressed among others by Komariah and Triatna (2006) suggest that visionary leadership is the ability of leaders to create, formulate, communicate and implement ideal ideas derived from him or as a result of social interaction among members of the organization and stakeholders who are believed to be ideals The organization in the future that must be achieved and realized through the commitment of all personnel. Another opinion presented by Goleman (2004) suggests that visionary leadership is a leadership pattern that seeks to encourage people toward dreams along with the most positive and most appropriate emotional climate impacts used when 
change requires a new vision or when a clear direction is needed. This opinion holds that visionary leadership is very important in driving the behavior of others or employees to improve their performance.

The results of statistical examination show that the learning organization has a direct and positive effect on the performance. This confirms in previous research that states that learning organization will improve employee performance. The study was conducted by Salim and Sulaiman ${ }^{[21]}$ which the results prove that the learning organization contributes to the performance. Research conducted by Ambula, Awino, and K'Obonyo (2016) ${ }^{[22]}$ to 108 manufacturing companies in Kenya proves that learning organization has a direct and significant impact on the company's financial and nonfinancial performance. Research conducted by Ratna et al ${ }^{[23]}$ to 50 managers of consulting firms show that organizational performance is influenced by learning organization. The results of this study are also reinforced by the opinion of Tjakraatmadja and Lantu (2006) which says that the learning organization is able to motivate all employees to be willing and able to improve their daily behavior, which is reflected in the improvement of perspective and thinking, and increase the intelligence and expansion of employees' insight. Another opinion by Mondy (2008) which states that the learning organization in a company will make the company realize the importance of training and development related to sustainable performance and willing to take appropriate action. The opinion of experts is essentially stated that the implementation of learning organization will cause employee performance will increase.

On the other hand, the test results on statistical examination that innovative behavior has a direct and positive effect on performance. The results of this research support research that has been done before, such as Marques and Ferreira (2009) ${ }^{[24]}$ which the results show that innovative behavior affect the company's performance. His research took place in a traditional industrial area of Portugal. The results of his research, among others, concluded that the company's innovation ability significantly influence the company's performance. Another research was conducted by Gunday et $\mathrm{al}^{[25]}$ who conducted research on 184 manufacturing companies in Turkey. The result of his research concludes that innovation has an effect on company performance. The results support expert opinion on innovative behavior which states that innovative behavior is ultimately aimed at improving organizational performance through enhancement of individual performance. With innovative behavior, employees can solve problems they encounter through the discovery of new ideas and implement the idea that will improve the performance of these employees. Such opinions include Carmeli, Meitar and Weiberg (2006) who stated that innovative behavior means a gradual process in which the individual recognizes a problem to derive new ideas and solutions, works to advance and build support for it, and produce a prototype that is applied or a model for Used as well as benefit the organization or part thereof. Another opinion was expressed by West and Farr as quoted by Kleysen and Street explaining that innovative behavior is an individual action directed toward generating, introducing or applying new, beneficial findings at every level of the organization.

Other test results state that visionary leadership has a direct and positive influence on learning organization. These results reinforce the results of previous research which states that visionary leadership has an influence on learning organization. The study was conducted by Schiena et $\mathrm{al}^{[26]}$ who conducted military leadership research that was associated with the Learning Organization. The results of his research show that leadership influences the learning organization both transformational leadership and transactional leadership. While research conducted by Demiricil et $a l^{[27]}$ who conducted research on 124 Employees in Altintas, Turkey. The results showed that visionary leadership had a direct positive effect on the dimension of Learning Organization. The results of this study are also in line with the opinions of experts such as Goleman (2004) who argue that visionary leadership is needed in changing organizational conditions and requires a new vision or vision change. Similarly, Sadu (2015) argues that visionary leadership consists of four variables: a) leaders, b) followers, c) situations and conditions, and d) organizational vision and mission. 
Other tests show that visionary leadership has a direct and positive influence on innovative behavior. This result confirms previous research conducted by Park, Moon and Hyun ${ }^{[28]}$ which states that leadership has an effect on innovative behavior. Although this research only sees leadership only and does not see from the aspect of visionary leadership, this research can give an idea that leadership is very influential in the employee's innovative behavior. These results reinforce the opinion of Sadu (2015) which states that visionary leadership has three aspects: a) high innovation, b) creativity, and c) the courage to face risks. The opinion would like to emphasize that visionary leadership will encourage employees to have innovative behavior.

Meanwhile, the results of testing on learning organization shows there is a direct and positive influence on innovative behavior. This result concurs with the results of previous research conducted by Liao, Fei, and Liu ${ }^{[29]}$ who sought to examine the link between knowledge inertia, organizational learning and organizational innovation. The results of his research, among others, indicate that the dimension of Learning Organization which includes the sharing of vision, openness of thought, and commitment to learning have a positive and significant effect on the organizational innovation dimension of both administrative and technical innovation. The results of this study also supported by research Škerlavaj, Song, and Lee (2010) which proves that learning organization culture has a strong positive influence on innovation.

\section{CONCLUSION}

The conclusions of the results of this study are 1) visionary leadership has a direct and positive impact on performance. 2) learning organization has a direct and positive effect on performance. 3) innovative behavior has a direct and positive effect on performance. 4) visionary leadership has a direct and positive influence on innovative behavior. 5) learning organization has a direct and positive effect on innovative behavior. 6) visionary leadership has a direct and positive influence on the learning organization.With the above conclusions, Tanjung Priok Customs and Excise Main Service Office should improve aspects of visionary leadership, learning organization and innovative behavior in order to improve the performance of Functional Officials of Customs and Excise Inspectors. The aspect of visionary leadership that needs to be improved is to set superior standards and reflect high ideas, clarify goals and direction, inspire spirit and keep commitment, have good pronunciation and easy to understand (effective communication), reflect the uniqueness of different organizations and competencies, and have a strong determination to realize the ideals. For the aspect of learning organization that needs to be improved is managerial commitment, system perspective, openness and experimentation, and transfer and integration of knowledge. While aspects that need to be improved on innovative behavior is to explore opportunities, generativity, conduct informative investigations, fight for, and apply.

\section{REFERENCES}

Aan Komariah dan Cepi Triatna. (2006).Visionary Leadership Menuju Sekolah Efektif. Jakarta: Bumi Aksara.

Abraham Carmeli, Ravit Meitar dan Jacob Weisberg. (2006). "Self-leadership Skills and Innovative Behavior at Work, ” International Journal of Manpower, Vol. 27, No. 1.

Ambula, Awino, and K'Obonyo. (2016). "Learning Organization and Performance of Large Manufacturing Firms”, DBA Africa Management Review, Vol 6, No. 1.

Ayse Cingöz, dan A. Asuman Akdogan. (2011). “An Empirical Examination of Performance and Image Outcome Expectation as Determinants of Innovative Behavior in The Workplace, "Procedia Social and Behavioral Sciences, Vol. 24.

Carla Susana Marques and João Ferreira. (2009). "SME Innovative Capacity, Competitive Advantage and Performance in a 'Traditional' Industrial Region of Portugal”, Journal of Technology Management Innovation, Volume 4, Issue 4.

Daniel Goleman. (2004).Kepemimpinan Berdasarkan Kecerdasan Emosi, terjemahan Susi PurwokoJakarta: Penerbit Gramedia Pustaka Utama. 
Demirici et all. (2012). "An Empirical Research On Relation Between Learning Organization And Visionary Leadership In Kutahya,Turkey”, Internation Symposium on Sustainable Development.

Dudung Juhana dan Reni Ambarsari. (2012). "Pengaruh Kepemimpinan Visioner dan Pengembangan Karir Terhadap Kepuasan Pegawai serta Implikasinya pada Kinerja Pegawai Dinas Pertambangan dan Energi Provinsi Jawa Barat,,Jurnal Ekonomi, Bisnis \& Enterpreneurship, Vol 6, No. 1.

Garetth R. Jones. (2013).Organizational Theory, Design, and Change, Seventh Edition. Essex: Pearson Education Limited.

Gi-Ryun Park, Gye-Wan Moon \& Sung-Eun Hyun. (2014). "An Impact of Self-leadership on Innovative Behaviour in Sports Educators and Understanding of Advanced Research",The SIJ Transactions on Industrial, Financial \& Business Management (IFBM), Vol. 2, No. 3.

Gurhan Gunday, et al. (2011). "Effects of innovation types on firm performance",International Journal of Production Economics, Volume 133, Issue 2.

Herman Aguinis. (2013).Performance Management. New Jersey: Pearson Education, Inc.

Islam Mohamed Salim and Mohamed Sulaiman. (2011)."Organizational Learning, Innovation and Performance: A Study of Malaysian Small and Medium Sized Enterprises, 'International Journal of Business and Management Vol. 6, No. 12.

Jann Hidajat Tjakraatmadja dan Donald Crestofel Lantu. (2006). Knowledge Management: dalam Konteks Organisasi Pembelajar. Bandung: Sekolah Bisnis dan Manajemen-Institut Teknologi Bandung.

Jason A. Colquit, Jeffery A. Lepine, dan Michael J. Wesson. (2009).Organizational Behavior. New York: McGraw-Hill International.

Jerald Greenberg dan Robert A. Baron. (2008).Behavior in Organizations, Ninth Edition. New Jersey: Pearson Prentice Hall Education,Inc.

John M. Ivancevich, Robert Konopaske, dan Michael T. Matteson. (2014).Organizational Behavior \& Management, Tenth Edition. New York: McGraw Hill Education.

Marno. (2007).Islam By Management and Leadership. Jakarta: Lintas Pustaka.

Michael Armstrong. (2006).A Handbook of Human Resource Management Practice. Tenth edition. Great Britain: Cambridge University Press. (2009).A Handbook of Human Resource Management Practice. London: Kogan Page.

Michael Drafke. (2009).The Human Side of Organizations, Tenth Edition. New Jersey: Pearson Prentice hall.

Raffaela Di Schiena, Geert Letens, Eileen Van Aken, and Jennife Farris. (2013). "Relationship Between Leadership and Characteristic of Learning Organization in Deployed Militery”. Units: An Exploratory Study, Administrative Sciences.

Ratna et all. (2014). "Impact of Learning Organization on Organizational Performance in Consulting Industry”, International Journal on Global Business Management and Research, Vol. 2, Issue 2.

Robert F. Kleysen, and Christopher T. Street. (2001). "Toward a Multi-Dimensional Measure of Individual Innovative Behavior, ” Journal of Intelectual Capital,Vol. 2, No. 3.

Sadia Cheema, Asia Akram and Farheen Javed. (2015). "Employee Engagement, and Visionary Leadership: Impact on Customer and Employee Satisfaction”, Journal of Bussiness Studies Quarterly, Volume 7, Number 2.

Samuel C. Certo, dan S. Trevis Certo. (2009).Modern Management: Concepts And Skills, Eleventh Edition. New Jersey: Pearson Education, Inc.

Shu-hsien Liao, Wu-Chen Fei, and Chih-Tang Liu. (2008). "Relationships between knowledge inertia, organizational learning and organization innovation”, Technovation.

Stephen P. Robbin and Mery Coutler. (2016).Management, Thirdteenth Edition. Essex: Pearson Education Limited.

Tjakraatmadja. (2006). Jann Hidayat, dan Donald Crestofel Lantu, Knowledge Management dalamKonteks Learning organization. Bandung: SMB ITB. 